\title{
POLA PERJALANAN TRANSPORTASI DARAT MASYARAKAT KABUPATEN TELUK BINTUNI
}

\author{
Risda Gracia Iwanggin \\ Program Studi Teknik Sipil Universitas Muhammadiyah Sorong \\ Jalan Pendidikan No 27 Kota Sorong, Propinsi Papua Barat \\ Email : risdha1098@gmail.com
}

\begin{abstract}
ABSTRAK
Kabupaten Teluk Bintuni merupakan salah satu kabupaten di Provinsi Papua Barat. Daerah ini merupakan pemekaran yang di bentuk bedasarkan UU Nomor 26 Tahun 2002 dengan ibukota di Bintuni. Kabupaten teluk Bintuni mempunyai potensi alam bidang migas, yaitu berupa cadangan $L N G$ yang sangat besar. Adanya LNG di kabupaten teluk bintuni menjadi harapan besar bagi masyarakat untuk meningkatkan kesejahteraan, kemajuan dan percepatan pembangunan. Kabupaten Teluk Bintuni sebagai salah satu kabupaten yang sedang berkembang perlu adanya penataan system pola transportasi yang baik untuk mendukung pembangunan di daerah ini., maka pengembangan sektor transportasi menjadi hal yang penting untuk ditinjau dan direncanakan secara baik. Dalam perkembangannya, masalah yang dihadapi oleh masyarakat di wilayah kabupaten teluk Bintuni adalah belum dipetakannya hubungan antara kemampuan masyarakat secara ekonomi dalam mengakses moda transportasi darat, kaitannya dengan kemampuan masyarakat untuk beraktifitas dengan moda transportasi kendaraan pribadi atau dengan menggunakan moda angkutan uтит. Dari semua hal tersebut maka perlu dilakukan kajian secara cermat dan detail, sehingga untuk kepentingan tersebut dan sebagai sumbangsih penulis terhadap masyarakat Kabupaten Teluk Bintuni, maka penulis tertarik untuk melakukan penelitian dengan judul Tinjauan Pola Perjalanan Transportasi Darat Masyarakat Kabupaten Teluk Bintuni. Tujuan penelitian ini yaitu untuk mengetahui karakteristik pola transportasi darat masyarakat Kabupaten Teluk Bintuni. Metode penelitian yang digunakan yaitu dengan tanya jawab atau wawancara kepada masyarakat kemudian pengolahan data. (tidak boleh lebih dari 150-200 kata)
\end{abstract}

Kata Kunci : transportasi; teluk bintuni; papua barat 


\section{PENDAHULUAN}

\section{Latar Belakang}

Kabupaten Teluk Bintuni merupakan salah satu kabupaten di Provinsi Papua Barat. Daerah ini merupakan pemekaran yang di bentuk bedasarkan UU Nomor 26 Tahun 2002 dengan ibukota di Bintuni. Kabupaten teluk bintuni terdiri dari 24 distrik di area seluas $18.658 \mathrm{~km} 2$ dengan jumlah penduduk sebanyak 53.564 jiwa ( website papua barat). Geografis kabupaten teluk bintuni berbatasan dengan kabupaten manokwari di sebelah utara, kabupaten teluk wondama di sebelah timur, kabupaten Fakfak dan Kaimana di sebelah selatan dan kabupaten Sorong Selatan di sebelah barat. Potensi wilayah di kabupaten teluk Bintuni iyalah obyek wisata cagar alam teluk Bintuni. Kabupaten teluk Bintuni mempunyai potensi alam bidang migas, yaitu berupa cadangan LNG yang sangat besar. Adanya LNG di kabupaten teluk bintuni menjadi harapan besar bagi masyarakat untuk meningkatkan kesejahteraan, kemajuan dan percepatan pembangunan. Kabupaten Teluk Bintuni sebagai salah satu kabupaten yang sedang berkembang perlu adanya penataan system pola transportasi yang baik untuk mendukung pembangunan di daerah ini., maka pengembangan sektor transportasi menjadi hal yang penting untuk ditinjau dan direncanakan secara baik.

Dalam perkembangannya, masalah yang dihadapi oleh masyarakat di wilayah kabupaten teluk Bintuni adalah belum dipetakannya hubungan antara kemampuan masyarakat secara ekonomi dalam mengakses moda transportasi darat, kaitannya dengan kemampuan masyarakat untuk beraktifitas dengan moda transportasi kendaraan pribadi atau dengan menggunakan moda angkutan umum. Dari semua hal tersebut maka perlu dilakukan kajian secara cermat dan detail, sehingga untuk kepentingan tersebut dan sebagai sumbangsih penulis terhadap masyarakat Kabupaten Teluk Bintuni, maka penulis tertarik untuk melakukan penelitian dengan judul Tinjauan Pola Perjalanan Transportasi Darat Masyarakat Kabupaten Teluk Bintuni.

\section{Tujuan Penelitian}

Penelitian ini bertujuan untuk mengetahui karakteristik pola transportasi darat masyarakat Kabupaten Teluk Bintuni

\section{STATE OF THE ART}

Adapun penelitian terdahulu yang terkait dengan penelitian ini adalah sebagai berikut :

1. Indahyani Hasim (2011) menyebutkan bahwa

Berdasarkan pada hasil penelitian dan pembahasan yang telah diuraikan sebelumnya maka dapat ditarikesimpulan sebagai berikut :

1. Perkembangan sarana dan prasarana transportasi darat dalam hal ini bertambahnya panjang jalan dan jumlah kendaraan sekalipun relative rendah tetapi memiliki hubungan yang erat dan saling terkait satu sama lain dengan pertumbuhan ekonomi di Kabupaten Merauke.Pengeluaran pemerintah atas infrastruktur berupa pembiayaan jalan mempunyai pengaruh positif dan signifikan terhadap pertumbuhan ekonomi di Kabupaten Merauke. Hal ini dapat dilihat dari aktifitas perekonomian yang meningkat akibat tersedianya infrastruktur yang memadai di Kabupaten Merauke sehingga memicu adanya pertumbuhan ekonomi yang lebih tinggi

2. EVA DEWI PURITA (2013) menyebutkan hasil penelitiannya adalah Dinas yang terkait dalam pengolahan transportasi umum di jalan malioboro Yogyakarta adalah Dinas Perhubungan, Dinas pemukiman dan Prasarana Wilayah dan juga dinas Parawisata dan budaya yang lebih di khususkan lagi ke UPT kawasan malioboro Yogyakarta. Masing-masing Dinas perhubungan adalah sebagai pihak yang membuat regulasi ataupun peraturan transportasi umum di jalan malioboro, dinas prmukiman dan prasaran Wilayah Kota yogyakarta memiliki peran sebagai penyedia fasilitas transportasi umum di kawasan ini sedangkan UPT seperti pemelihara an ketertiban dan juga sarana prasarana kawasan malioboro. 
Hambatan yang di hadapi oleh dinas pemukiman dan prasaran wilayah kota Yogyakarta adalah masalah ekonomi merupakan hambatan yang sangant mendasar terkait pengolahan pengolahan transportasi umum untuk mencari nafka di sepanajang jalan malioboro. Solusi yang di lakukan oleh pemerintah dalam pengolahan transportasi umum di jalan malioboro. Mengoptimalkan ruangan yang ada dengan tidak mengabaikan hambatan yang ada. Dengan ruang milik jalan yang sangat terbatas di kawasan malioboro, di kembangkan dengan melakukan berbagai pembangunan yang dapat memanfaatkan lahan yang tersedia.

\section{METODE}

\section{Tahapan Penelitian}

Metode penelitian yang dipakai disini yaitu dengan melakukan proses wawancara atau tanya jawab kepada masyarakat sekitar

Semua metode penulisan dan analisa dalam artikel ilmiah ini merujuk pada panduan penulisan tugas akhir Fakultas Teknik Universitas Muhammadiyah Sorong tahun 2014 (Pristianto, Amri, \& Rusdi, 2014).

\section{REFERENSI}

Alvinsyah \& Soehodho, S., 1997, Dasar - Dasar Sistem Transportasi, Laboratorium Transportasi Jurusan Sipil Fakultas Teknik Universitas Indonesia, Jakarta.

BPS Raja Apat, 2018. Distrik Teluk Mayalibit dalam Angka Tahun 2018. Badan Pusat Statistik (BPS) Kabupaten Raja Ampat, Waisai.

Kamarwan, S.S., 1997, Sistem Transportasi, Penerbit Gunadarma, Jakarta

Morlok, E.K., 1988, Pengantar Teknik dan Perencanaan Transportasi, Penerbit Erlangga, Jakarta Pusat.

Nazir, M., 1983, Metodologi Penelitian, Penerbit Ghalia Indonesia, Jakarta.

Pristianto, H., Amri, I., \& Rusdi, A. (2014, May 9). Pedoman Penulisan Tugas Akhir Fakultas Teknik Universitas Muhammadiyah Sorong 2014. http://doi.org/10.17605/OSF.IO/4VTJM.

Tamin, O.Z., 1997, Perencanaan dan Permodelan Transportasi, Institut Teknologi Bandung.

Usman, H. \& Akbar, R.P.S., 2006, Pengantar Statistika, Penerbit PT. Bumi Aksara, Jakarta.

Warpani, S., 1981, Perencanaan Transport, Institut Teknologi Bandung.

Warpani, S., 1988, Rekayasa Lalu Lintas, Penerbit Bhratara, Jakarta. 